\title{
Varying abundance and dispersal of the two-spotted spider mite (Tetranychus urticae Koch, 1836, Acari: Prostigmata: Tetranychidae) on Mi-tomato plants differing in allelic combination
}

\author{
MONIKA GODZINA, MAŁGORZATA KIEŁKIEWICZ and KATARZYNA SZYMCZYKIEWICZ
}

Department of Applied Entomology, Faculty of Horticulture and Landscape Architecture, Warsaw University of Life Sciences - SGGW, Nowoursynowska 159, 02-776 Warsaw, Poland Corresponding author: Małgorzata Kiełkiewicz, malgorzata_kielkiewicz@sggw.pl

\begin{abstract}
It is well known that the presence of the Mi-1.2 gene determines the resistance of tomato plants (Solanum lycopersicum L.) to 3 root-knot nematode species and some insect herbivores of the order Hemiptera. In this study, the density and dispersal of two-spotted spider mites (Tetranychus urticae) on tomato plants of 4 cultivars were evaluated under greenhouse conditions, to find out whether tomatoes differing in allelic combination of the Mi-1.2 gene exhibit similar or different resistance to the mite pest. The results show, for the first time, that the same initial number of mites develops into populations that vary in abundance and distribution depending on tomato allelic composition of the Mi-1.2 gene. The results indicate that the mite-pest develops more slowly on tomato plants of cultivar 'Motelle', carrying 2 dominant alleles for the Mi-1.2 gene, than on heterozygous 'Altess F1' tomatoes and both cultivars carrying only recessive alleles of this gene: 'Moneymaker' and 'Plaisence F1'. This suggests that the Mi1.2 gene may be involved in tomato resistance against spider mites when this dominant gene is expressed homozygously, but this needs to be verified by further research.
\end{abstract}

Keywords: spatio-temporal spread, distribution, Solanum lycopersicum L., spider mites, Tetranychus urticae, Mi-1.2 gene

\section{INTRODUCTION}

During cultivation, tomato (Solanum lycopersicum L., 1753) plants are exposed to various stress factors, both biotic (pathogens, pests) and abiotic (drought, salinity, extremes in temperature, UV light radiation, etc.), which limit plant growth and yield. The majority of commercially available tomato cultivars have been equipped with traits of resistance to some pathogens, but only few tomato cultivars carry the Mi-1.2 gene, which was introduced with traditional breeding methods (SмIтн 1944). The presence of the Mi-1.2 gene product significantly reduces the development of 3 species of root-knot nematodes (Meloidogyne incognita Kofoid et White, 1919; M. 
arenaria Neal, 1889; and M. javanica Treub, 1885) (Milligan et al. 1998) and thus limits the losses in tomato plant yield (TALAVERA et al. 2009). Studies in recent years have shown that the $\mathrm{Mi}-1.2$ gene also determines the resistance of tomato plants to some insect herbivores of the order Hemiptera, such as the potato aphid (Macrosiphum euphorbiae Thomas, 1877) (KALOSHIAN et al 1995; Rossi et al. 1998; GoGGIN et al. 2001), the sweet potato whitefly (Bemisia tabaci Genn., 1889) (NomBELA et al. 2003), and the tomato psyllid (Bactericera cockerelli Sulc) (CASTEEL et al. 2006).

Mite herbivores, very much like aphids or whiteflies (insects of the order Hemiptera), are equipped with piercing-sucking mouthparts, but mites differ from the hemipterans in their mode of feeding and leaf tissue damage. Aphids and whiteflies feed on phloem sap, whereas mites feed on mesophyll cell content. The two-spotted spider mite (Tetranychus urticae Koch, 1836, Acari: Prostigmata: Tetranychidae) is an economically important mite-pest for a number of crop plants and may heavily infest tomato plants (NiHoul et al. 1991; KIEŁKIEWICZ 1996, 2003). So far, there are no data available on $\mathrm{Mi}$-tomato-mite interactions, except an assessment of population parameters of $T$. urticae on detached tomato leaves carrying dominant or recessive alleles of the $\mathrm{Mi}$-1.2 gene, showing comparable mite reproductive potential (GoDZINA et al. 2010a). The assessment of spatio-temporal mite dynamics on intact plants seems to be a more reliable indicator of $M i$-tomato susceptibility and/or resistance to this arthropod pest. Therefore, in this study, mite density and dispersal on tomato plants of 4 cultivars were evaluated under greenhouse conditions to find out whether tomatoes differing in allelic combination of the $M i-1.2$ gene exhibit similar or different resistance to the mite pest.

\section{MATERIALS AND METHODS}

Four tomato cultivars carrying different or the same form of the Mi-1.2 gene were chosen: 2 cultivars from the INRA gene bank (France), i.e. 'Motelle' (dominant homozygote for the Mi-1.2 gene) and 'Moneymaker' (recessive homozygote); and 2 commercially available cultivars, i.e. 'Altess F1' (heterozygote) and 'Plaisence F1' (recessive homozygote) (DeRuiter, Switzerland). Plants of all cultivars were grown in a greenhouse in a peat substrate from 21 March to 3 July 2009. In the present study, 9-week-old plants were used, as it is known from literature that the $M i-1.2$ mediates tomato resistance to insect pests but does not reveal itself until plants reach the age of 6 weeks (GoGgIN et al. 2004). The mean number of leaves per plant was 15 in cultivars 'Motelle' and 'Moneymaker' and 13 in 'Altess F1' and 'Plaisence F1'. Plants of all cultivars were divided into 2 groups: the control (not mite-infested, $n=16$ ) and the mite-infested group $(n=16)$.

Plants were artificially infested with young females of $T$. urticae from a colony established on the commercial tomato cultivar 'Robin F1' (PNOS, Ożarów Mazowiecki, Poland) in the greenhouse. On the first compound leaf under the first cluster, 25 young females were placed (i.e. 5 females on each of 5 leaflets). Using a magnifying glass, all mobile stages of T. urticae were counted on each leaf of each plant once a week for 6 weeks. The density of the mite-pest was expressed as the number of mobile stages per leaf and per plant. 
Differences in the density of mobile stages between cultivars were compared using one-way analysis of variance (ANOVA) followed by the Tukey honestly significant difference (HSD) test (Statgraphics ${ }^{\circledR}$ Plus for Windows 4.1). When the data were not normally distributed, the non-parametric test of Kruskal-Wallis was used instead. In each analysis, significance was assumed at $P=0.05$.

\section{RESULTS}

The dynamics of T. urticae population development in all cultivars (Fig. 1) shows that the equal initial number of $T$. urticae on leaves of all cultivars multiplied similarly (on average 4-fold) until the $3^{\text {rd }}$ week of observations (4 June 2009). From the beginning of the $4^{\text {th }}$ week, mite density started to differ among the cultivars examined ('Moneymaker', 'Motelle', 'Altess F1' and 'Plaisence F1') (Fig. 1; Fig. 4; Table 1). After 6 weeks, the largest number of mites occurred on plants of commercial cultivars ('Altess F1' and 'Plaisence F1'), while the number of individuals on plants of cultivars 'Motelle' and 'Moneymaker' was significantly lower (Kruskal-Wallis test: $H=17.61 ; P=0.0005$ ) (Fig. 1; Fig. 4).

The mobile stages of $T$. urticae started moving up the plant noticeably at the beginning of the $4^{\text {th }}$ week and continued their upward movement as the population density increased (Table 1; Fig. 2a-b; Fig. 3a-b). The distribution of the mobile stages on

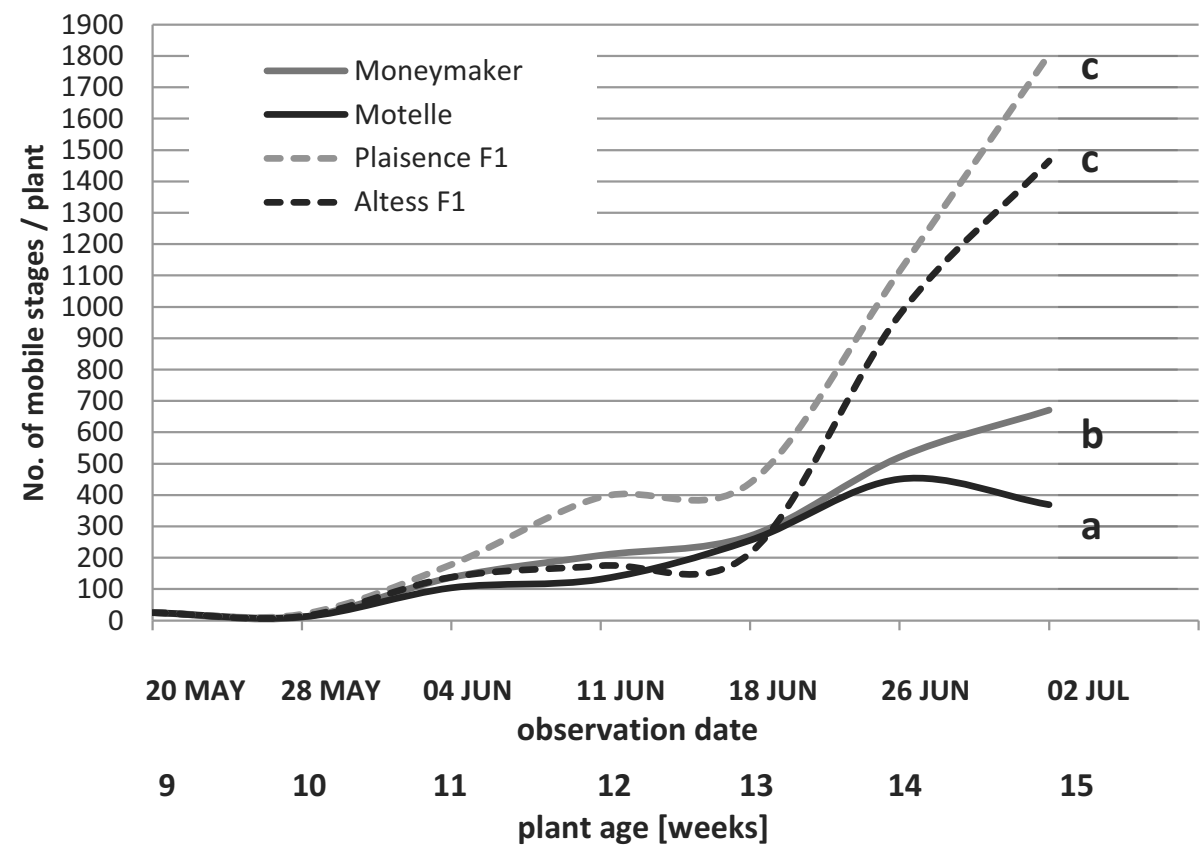

Fig. 1. Comparison of T. urticae population development on 4 tomato cultivars with different allelic combinations of the Mi-1.2 gene. Different letters indicate significant differences (02 Jul 2009) (Kruskal-Wallis test: $H=17.61 ; P=0.0005$ ) 


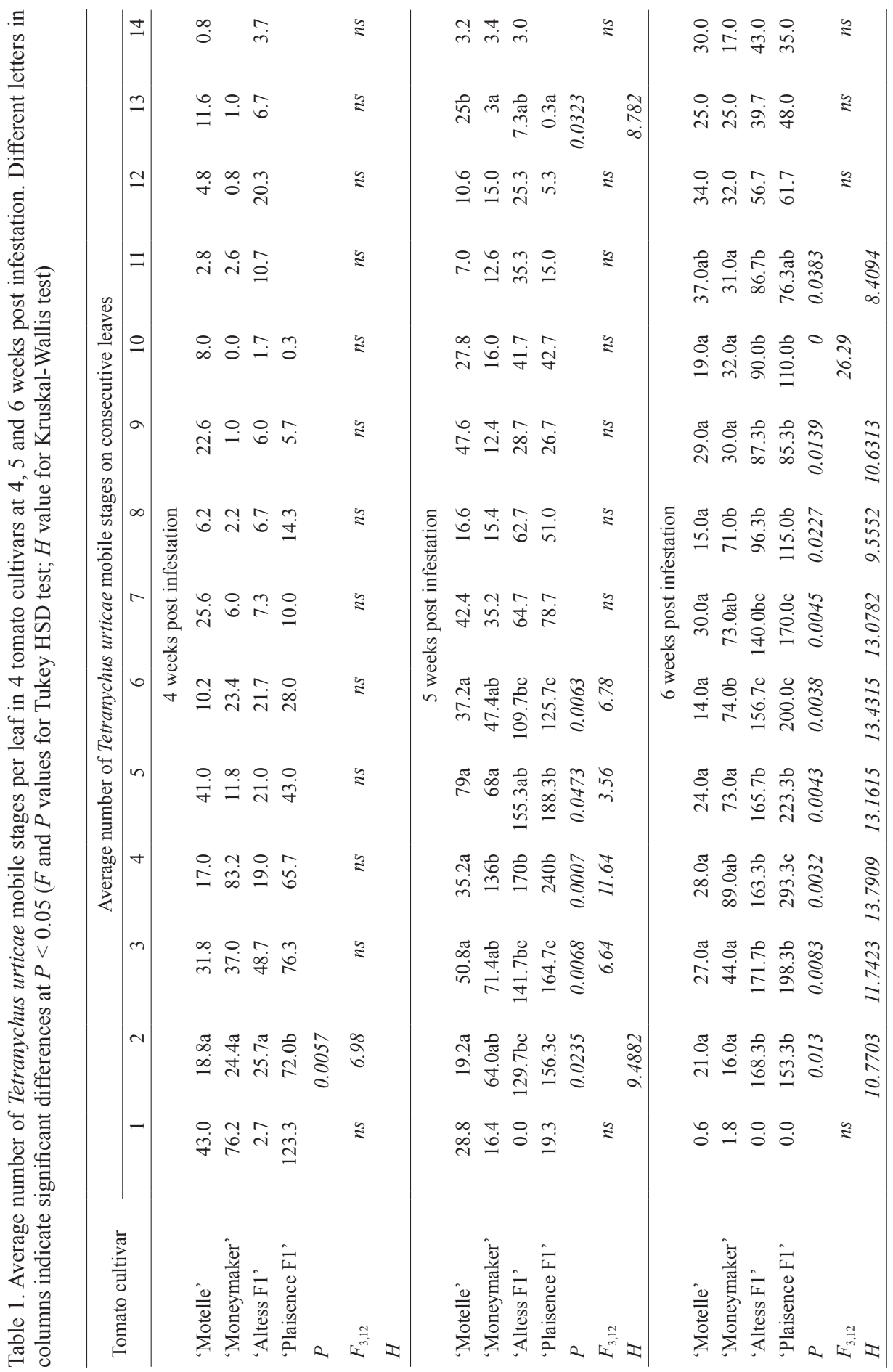




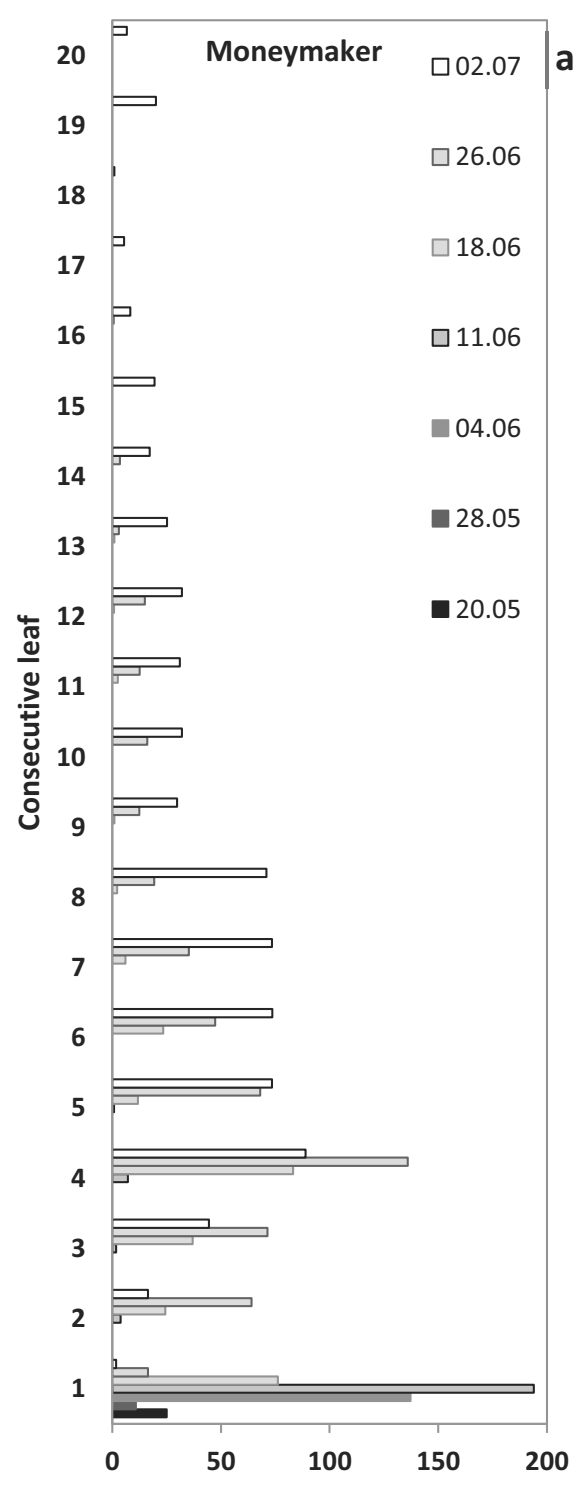

No. of mobile stages /leaf

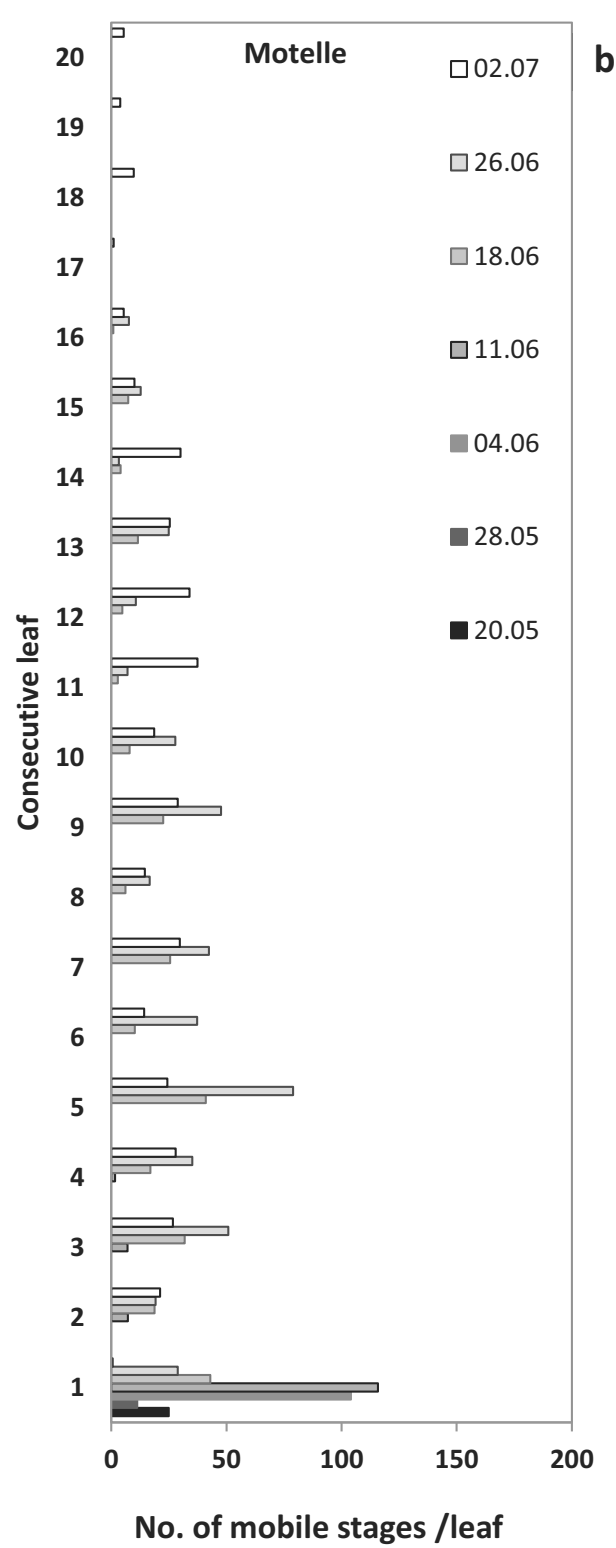

Fig. 2. Dispersal of T. urticae mobile stages on tomato plants of cultivars 'Moneymaker' (a) and 'Motelle' (b) during 6 weeks of population development. The initial number of T. urticae was 25 females per leaf (20 May 2009) 


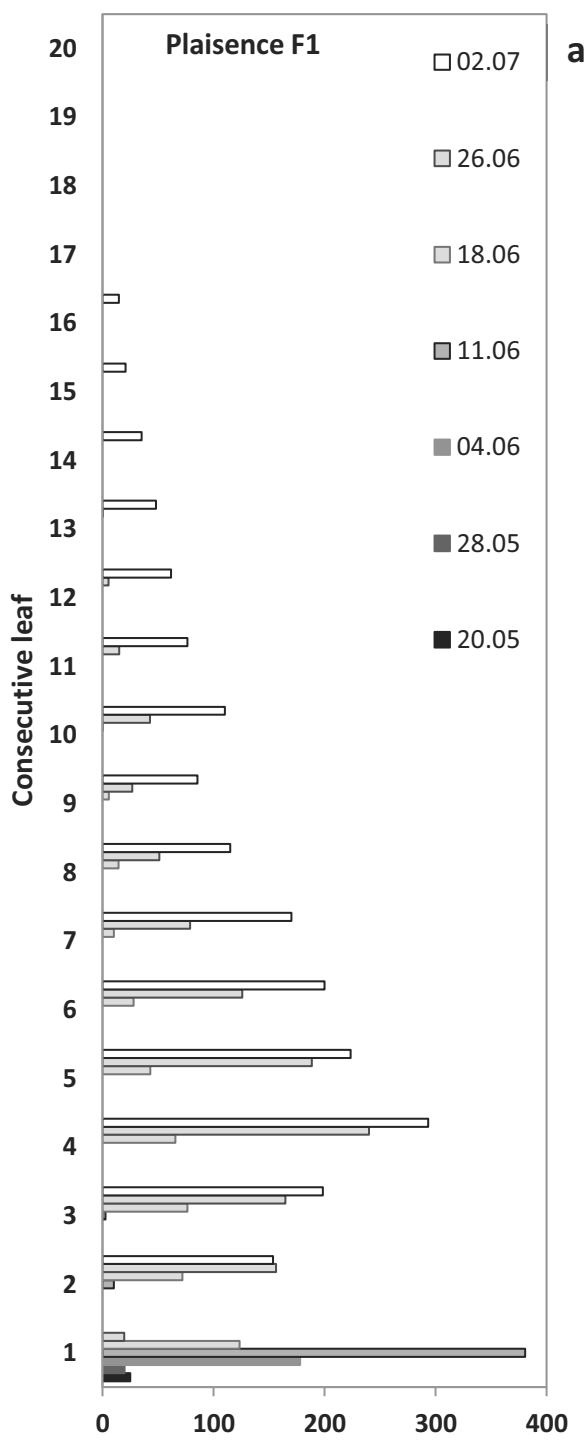

No. of mobile stages /leaf

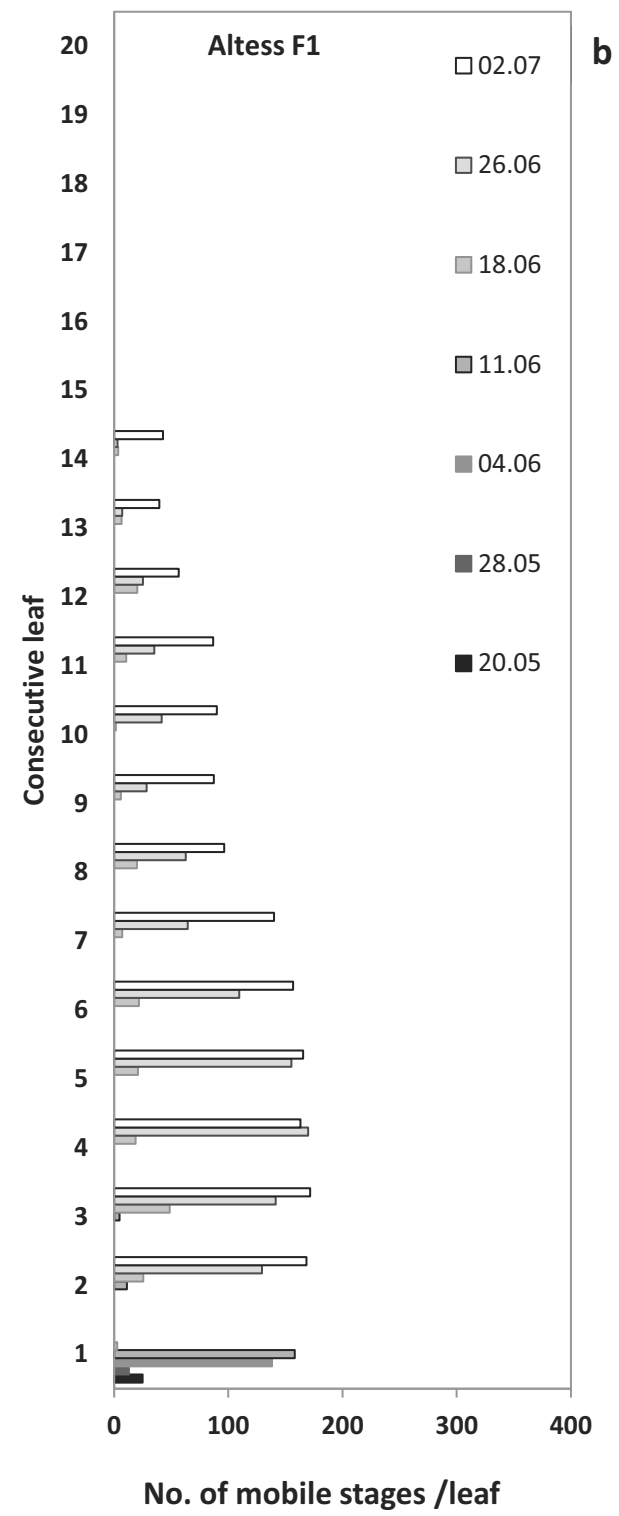

No. of mobile stages /leaf

Fig. 3. Dispersal of T. urticae mobile stages on tomato plants of cultivars 'Plaisence F1' (a) and 'Altess F1' (b) during 6 weeks of population development. The initial number of T. urticae was 25 females per leaf (20 May 2009) 

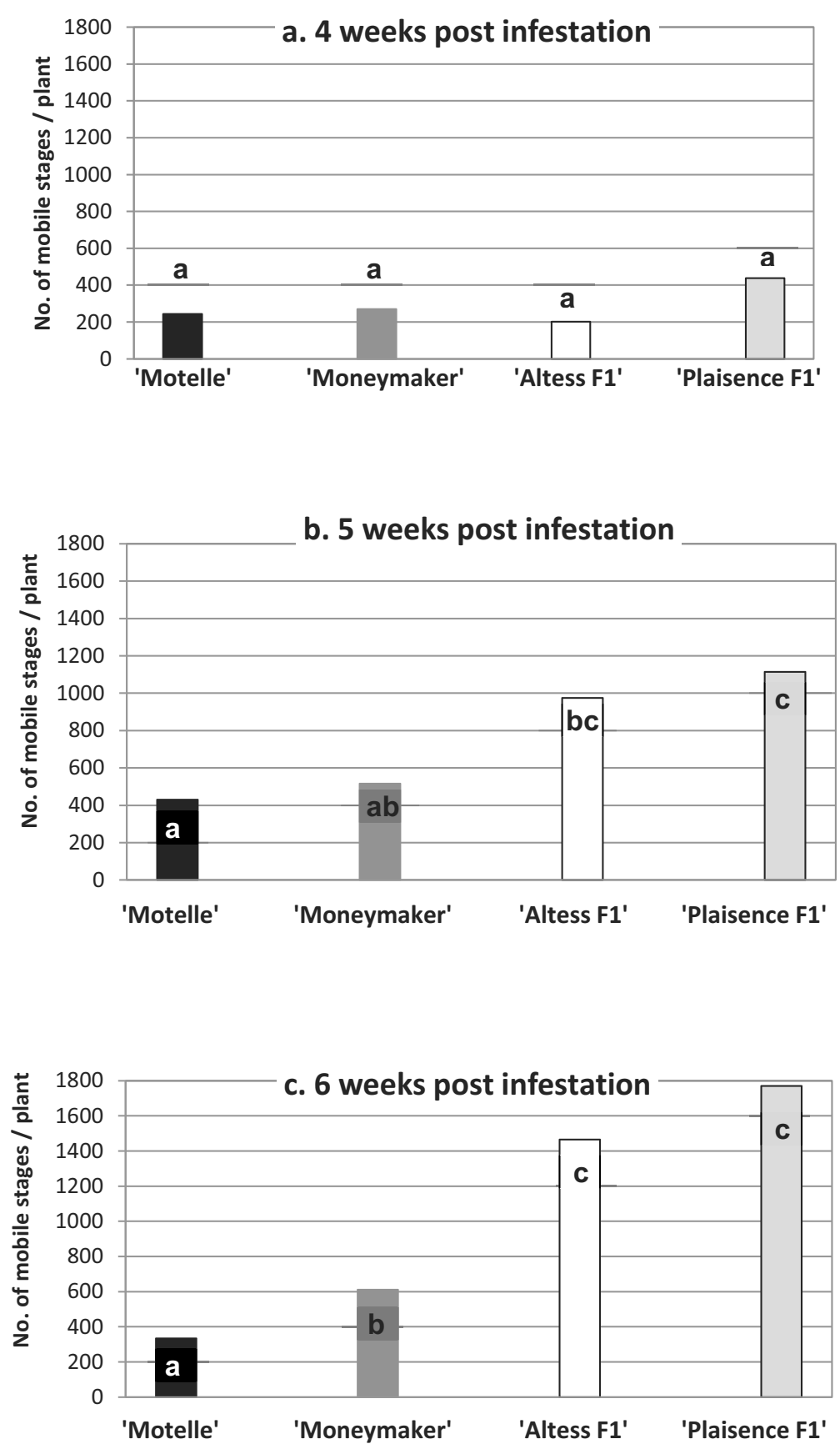

Fig. 4. Comparison of average numbers of T. urticae mobile stages per plant in 4 tomato cultivars at 4 (a), 5 (b) and 6 (c) weeks post infestation. Different letters indicate significant differences (Tukey HSD test) 
'Moneymaker' and 'Plaisence F1' plants followed a similar pattern - the mites were most abundant in the middle parts of the shoots (Table 1; Fig. 2a; Fig. 3a). In contrast, on 'Motelle' and 'Altess F1' plants, the mites were spread more evenly (Table 1; Fig. 2b; Fig. 3b). Evidently, the average density of T. urticae on 'Altess F1' and 'Plaisence F1' plants significantly exceeded the average density of mites on 'Motelle' and 'Moneymaker' plants at 6 weeks post infestation $(F=13.28 ; P=0.0041)$ (Fig. 1; Fig. 4). However, the average number of leaves on 'Altess F1' and 'Plaisence F1'plants was lower than on 'Motelle'and 'Moneymaker' plants (data not shown).

\section{DISCUSSION}

Previous results indicated that tomato plants carrying the $M i-1.2$ gene are resistant not only to nematodes (Milligan et al. 1998) but also to some insect herbivores of the order Hemiptera, with a piercing-sucking mode of feeding, that take in nutrients from phloem tissues (Kaloshian et al 1995; Rossi et al. 1998; GoGGIN et al. 2001; Nombela et al. 2003; CASTEEL et al. 2006). The question arises if the presence of the Mi-1.2 gene affects T. urticae, which is a common pest of tomatoes and feeds from leaf mesophyll cell content. We have previously observed that under laboratory conditions, population parameters of T. urticae on leaves detached from tomato plants carrying dominant or recessive Mi-1.2 alleles did not differ (GoDzINA et al. 2010a). Furthermore, a similar value of the intrinsic rate of natural increase $\left(r_{m}\right)$ of $T$. urticae, observed on both tomato genotypes, suggested a comparable increase of mite population capacity. Contrary to that assumption, the present study demonstrates that T. urticae population density and distribution on intact tomato plants growing under greenhouse conditions varies depending on the allelic combination of the Mi-1.2 gene. The results obtained here, for the first time, indicate that the mite-pest develops more slowly on tomato plants of cultivar 'Motelle', carrying 2 dominant alleles for the Mi-1.2 gene, than on heterozygous 'Altess F1' tomatoes and both cultivars carrying only recessive alleles of this gene: 'Moneymaker' and 'Plaisence F1'. However, the differences in the performance of T. urticae on tomato plants with and without the $M i-1.2$ gene were not as spectacular as in the case of differences in the performance of potato aphids that fed on dominant or recessive homozygous tomato plants (Kaloshian et al. 1995; Rossi et al. 1998; GogGin et al. 2004; Godzina et al. 2010b). The strong inhibition of aphids' feeding on $\mathrm{Mi}$-tomato plants may be a result of the Mi-1.2 gene influence on phloem structure and content (KALOSHIAN et al. 2000). Thus T. urticae, as a mesophyll-feeder, may be less sensitive to tomato plant resistance activated by the Mi-1.2 gene. However, recently it has been found that $M i$-mediated aphid resistance also involves effective factors acting possibly in the mesophyll, epidermis and/or in the intercellular spaces (PALLIPPARAMBIL et al. 2010).

Numerous studies have shown that plant resistance affects pest performance by single or combined effects of antixenosis, antibiosis and/or tolerance (Sмітн 2005). For example, type VI trichomes on the leaf surface of cultivated tomatoes contribute to their resistance to arthropod herbivores, including mite-pests, by: (1) mechanical entrapment of pest in metabolites exuded by trichomes; and/or (2) the direct toxic/repellent effect of trichome metabolites on the pest (SimMONS \& GURR 2005; KanG et al. 
2010). Therefore, these morphological/biochemical features of $M i$-tomato cultivars can potentially have a negative effect on T. urticae population development. Currently, both the density and chemical composition of type VI glands of Mi-tomatoes are under investigation. Further study is also needed to assess the interactions between Mi-1.2-gene-mediated tomato resistance against nematodes or aphids and its resistance to mites.

During the experimental period, the smallest population of $T$. urticae evolved on 'Motelle' plants (dominant homozygotes for the Mi-1.2 gene) and the largest on 'Plaisence F1' plants (recessive homozygotes). In relation to the T. urticae density on 'Motelle' and 'Plaisence F1' plants, the mite population density on 'Altess F1' (heterozygote) and 'Moneymaker' (recessive homozygote) plants reached intermediate values. Furthermore, T. urticae developed much better on commercial cultivars ('Altess F1', 'Plaisence F1') than on those from the gene bank ('Motelle', 'Moneymaker'). 'Altess F1' and 'Plaisence F1' are common greenhouse cultivars. Therefore, we presume that they may offer much better nutritional qualities to mites than 'Motelle' and 'Moneymaker' cultivars.

Studies on the behaviour and development of T. urticae and the carmine spider mite (T. cinnabarinus Boisduval, 1867) in greenhouse conditions on commercial cultivars of cucumber and tomato, respectively (KIEtKIEWICZ \& ToMCZYK 1987; KIEEKIEWICZ 1996, 2003), demonstrate that the host-plant species and cultivar greatly affect its population dynamics and dispersal. In the present study, the distribution of mobile stages on tomato plants varied depending on the presence of the Mi-1.2 gene. On the tomato cultivars 'Moneymaker' and 'Plaisence F1' (recessive homozygotes), mites found the best conditions to feed in the middle parts of the plant. This is in line with the earlier results of KIEE KIEWICZ $(1996,2003)$ proving that T. cinnabarinus finds the best conditions to feed and multiply in the middle part of tomato shoots in greenhouse conditions. By contrast, in the present study, on the tomato plants with 1-2 dominant alleles of the gene Mi-1.2 ('Altess F1' and 'Motelle', respectively), mite-pests settled rather evenly on all available leaves.

In conclusion, it has been shown for the first time that the same initial number of T. urticae, under greenhouse conditions, develops a population that varies in abundance and distribution depending on the allelic composition of the Mi-1.2 gene. Generally, mite population densities on the commercial tomato cultivars were higher than on plants from the gene bank. The smallest population of mites developed on tomato plants of the cultivar with 2 dominant alleles for the Mi-1.2 gene, and the largest on plants of commercial cultivar with 2 recessive alleles. In relation to the above-mentioned homozygous cultivars, the mite population density on a heterozygous cultivar had intermediate values. This suggests that the Mi-1.2 gene may be involved in the resistance of the tomato plants against $T$. urticae when this dominant gene is expressed homozygously. Further advances in the understanding of the mechanisms of this phenomenon are needed.

Acknowledgements: We would like to thank Dr Teresa Kotlińska for providing tomato seeds for this study. 


\section{REFERENCES}

Casteel C. L., Walling L. L., Paine T. D. 2006. Behavior and biology of the tomato psyllid, Bactericera cockerelli, in response to the Mi-1.2 gene. Entomol. Exp. Apel. 121: 67-72.

Godzina M., KieŁKiewicz M., Szymczykiewicz K. 2010a. Tomato carrying Mi-1.2 gene as a hostplant to the two-spotted spider mite (Tetranychus urticae Koch): results of laboratory evaluation. Vegetable Crops Research Bulletin 72: 15-24.

Godzina M., Staniaszek M., KietKiewicz M. 2010b. Relevance of the MI23 marker and the potato aphid biology as indicators of tomato plant (Solanum lycopersicum L.) resistance to some pests. Vegetable Crops Research Bulletin 72: 25-33.

Goggin F. L., Gowri S., Williamson V. M., Ullman D. E. 2004. Developmental regulation of Mimediated aphid resistance is independent of Mi-1.2 transcript levels. Mol. Plant-Microbe Interact. 17: 532-536.

Goggin F. L., Williamson V. M., Ullman D. E. 2001. Variability in the response Macrosiphum euphorbiae and Myzus persicae (Hemiptera: Aphididae) to the tomato resistance gene Mi. Environ. Entomol. 30: 101-106.

Kaloshian I., Kinsey M. G., Williamson V. M., Ullman D. E. 2000. Mi-mediated resistance against the potato aphid Macrosiphum euphorbiae (Hemiptera: Aphididae) limits sieve element ingestion. Environ. Entomol. 29: 690-695.

Kaloshian I., Lange W. H., Williamson V. M. 1995. An aphid resistance locus is tightly linked to the nematode resistance gene, $M i$, in tomato. Proc. Natl. Acad. Sci. USA 92: 622-625.

Kang J. H., Shi F., Jones A. D., Marks M. D., Howe G. A. 2010. Distortion of trichome morphology by the hairless mutation of tomato affects leaf surface chemistry. J. Exp. Bot. 61: 1053-1064.

KIEŁKIEWICZ M. 1996. Dispersal of Tetranychus cinnabarinus on various tomato cultivar. Entomol. Exp. Appl. 80: 254-257.

KIEŁKIEWICZ M. 2003. Strategie obronne roślin pomidorów (Lycopersicon esculentum Miller) wobec przędziorka szklarniowca (Tetranychus cinnabarinus Boisduval, Acari: Tetranychidae). Wydawnictwo SGGW, Warszawa.

KięKiewicz M., TomcZYK A. 1987. Podatność odmian pomidorów i ogórków na przędziorki. Materiały XXVI Sesji Naukowej IOR. 27: 17-22.

Milligan S. B., Bodeau J., Yaghoobi J., Kaloshian I., Zabel P., Williamson V. M. 1998. The root - knot nematode resistance gene $M i$ from tomato is a member of leucine zipper, nucleotide binding, leucine - rich repeat family of plant genes. Plant Cell. 10: 1307-1319

Nombela G., Williamson V. M., Muniz M. 2003. The root - knot nematode resistance gene $M i-1.2$ of tomato is responsible for resistance against the whitefly Bemisia tabaci. Mol. Plant-Microbe Interact. 16: 645-649.

Nihoul P., Van Impe G., Hance T. 1991. Characterizing indices of damage to tomato by the twospotted spider mite, Tetranychus urticae Koch (Acari: Tetranychidae) to achieve biological control. J. Hort. Sci. 66: 643-648.

Pallipparambil G. R., Reese J. C., Avila C. A., Louis J. M., Goggin F. L. 2010. Mi-mediated aphid resistance in tomato: tissue localization and impact on the feeding behavior of two potato aphid clones with differing levels of virulence. Entomol. Exp. Appl. 135: 295-307.

Rossi M., Goggin F. L., Milligan S. B., Kaloshian I., Ullman D. E., Williamson V. M. 1998. The nematode resistance gene $\mathrm{Mi}$ of tomato confers resistance against the potato aphid. Proc. Natl. Acad. Sci. USA 95: 9750-9754.

Simmons A. T., GurR G. M. 2005. Trichomes of Lycopersicon species and their hybrids: effects on pests and natural enemies. Agric. For. Entomol. 7: 265-276.

Sмітн C. M. 2005. Plant resistance to arthropods. Molecular and Conventional Approaches. Springer, Dordrecht, The Netherlands. 
Sмith P. G. 1944. Embryo culture of a tomato species hybrid. Proc. Am. Soc. Hortic. Sci. 44: 413-416.

Talavera M., Verdejo-Lucas S., Ornat C., Torres J., Vela M. D., Macias F. J., Cortada L., Arias D. J., Valero J., Sorribas F. J. 2009. Crop rotations with Mi gene resistant and susceptible tomato cultivars for management of root-knot nematodes in plastic houses. Crop Prot. 28: 662-667. 